総 説

\title{
保護地域のジレンマ 生物多様性と文化の相克一
}

\author{
原田一宏*,1
}

\begin{abstract}
原田一宏：保護地域のジレンマー生物多様性と文化の相克一 日林誌 $87: 261 \sim 271,2005$ 本研究の目的は, 生物多様 性保全を目指した保護地域管理の実態を把握することにより，保護地域に居住する地域住民のおかれている立場を明らかに し，保護地域の資源をめぐる錯綜した自然と人間の関係を検証することにある。昨今，地球上の貴重な生物多様性を保全す るために，国際的な議論が活発に行われるとともに，世界中で多くの保護地域が設定されている。保護地域に指定される地 域は，地域住民が居住している地域と重なることが多く，保護地域設定の際に地域住民の権利を保証する必要がある。しか し, 自然保護主義者や行政官は, 保護地域設定によって生物多様性保全を実現し, 保護地域の設定や, 保護地域でのエコ・ ツーリズムによって，外貨獲得に成功したものの，保護地域は，地域住民への経済的な利益をほとんどもたらさず，むしろ， 彼らの慣習的な生活の脅威になることが多かった。このような，ステークホルダーによる自然への異なる接し方が，生物多 様性と文化の保全をめぐっての対立構造を生じさせる原因となった。今後は，地方にも保護地域管理の責任の一部を委譲す ること,NGO などの第三者の協力を得つつ，地域住民が，自立した組織として政府と直接交涉し，政府と地域住民の両者と もに利益がもたらされるような管理システムを構築していくことが必要である。 キーワード：エコ・ツーリズム, 自然と人間の関係, 生物多様性, 地域住民, 保護地域
\end{abstract}

Harada, K.: Dilemma of Protected Areas: Conflicts between Biodiversity and Culture. J. Jpn. For. Soc. 87: 261 271, 2005 The purpose of this paper is to understand the current situation of local dwellers in protected areas, by revealing the reality of biodiversity conservation management in those areas, and to examine the tangled relationships between nature and human-kind. In order to protect precious biodiversity on earth, discussions on this topic are carried out internationally, and protected areas are increasing throughout the world. Because local dwellers often occupy the areas which are also designated as protected areas, the rights of those people should be ensured. While preservationists and government authorities have achieved biodiversity conservation and succeeded in acquiring foreign currency by establishing protected areas and eco-tourism in them, those did not contribute to the economic benefits of local dwellers, but rather, jeopardized their customary lifestyles. These different attitudes towards nature by different stakeholders are causing conflicts between biodiversity and culture. It is indispensable to delegate some responsibilities for the management of protected areas from the central to the local, and to construct the management system which can share benefits among stakeholders, by providing direct meeting between self-supported local organizations and governments in conjunction with third parties such as NGOs.

Key words : biodiversity, eco-tourism, local people, protected areas, relationship between nature and human

\section{I. は じめに}

昨今の環境破壞は, 地球上の動植物を絶滅の危機へと導 き, 自然生態系の修復が困難な状況を創り出してきた。特 に, 森林は, 「遺伝子の多様性」,「種の多様性」,「生態系の 多様性」など, 生物多様性の宝庫であり, これらの消失は 全人類にとって大きな損失である。このような森林を保護 するために, 1970 年代以降, 東南アジアをはじめとした世 界各地に多くの保護地域が設定された（注 1 )。しかし, 保 護地域に設定される地域は, もともとその地に長年居住し てきた地域住民の生活空間と重なる場合が多い。そこで, 保護地域を設定する際に, 地域住民の森林および土地の利 用や管理の権利をどのように取り扱うかが問題となる。国 際自然保護連合 (IUCN) は, 現在の持続可能な開発の理
念や国際的な取り決めを尊重しつつも，それと同時に地域 住民の権利も認める立場をとっている（Beltran, 2000: ix$\mathrm{x})$ 。確かに, グローバルな視点からの議論では, 地域住民 の権利が保障され，地域住民の参加を伴う資源の共同管理 が謳われている。しかし, 東南アジアのローカルな現場で は, 動植物の保全を目的とした保護地域管理に多くの関心 が払われている一方で，その地域に住む人々の文化的社会 的意義は十分に考慮されてこなかった (Harada, 2003; 原 田，2001；百村， 2003 ; 佐藤，2002；土屋ら，2003）。生物 多様性に関わる議論についても同様に，国際的な条約や行 動原理に揭げられた理想とは裏腹に，地域住民と保護地域 の共存は実現困難であり, 国際的な取り決めと, ローカル な現実との間には相変わらず大きな隔たりが存在してき た。政府主導による政策形成や，国際会議，政府間交渉と

* 連絡・別刷請求先 (Corresponding author) E-mail : harada @ iges.or.jp

1 (財) 地球環境戦略研究機関・森林保全プロジェクト (240-0115 神奈川県三浦郡葉山町上山口 2108-11)

Forest Conservation Project, Institute for Global Environmental Strategies, 2108-11 Kamiyamaguchi, Hayama, Miura, Kanagawa 240-0115, Japan.

(2003 年 12 月 17 日受付 ; 2005 年 3 月 2 日受理) 
いった政治的な枠組みの中では, 地域への利益をもたらす どころか，かえって地域住民を窮地へと追い込むシナリオ が創りあげられてきた。

本研究の目的は, 近年の保護地域の動向を把握すること によって，保護地域をめぐる自然と人間の関わり方につい て論じることである。具体的な課題としては以下のと㧍り である。第一に, 既存研究のレビューによって, 自然と人 間の関係をめぐる諸思想を紹介するとともに，これらの思 想を分類するための枠組みを構築する。第二に, 既存研究 のレビューによって, 自然と人間の関係の一事例として保 護地域を取り上げる。まず，国立公園制度の先駆的事例で あるアメリカの国立公園政策を取り上げる。次に, 自然保 護, 外貨獲得, エコ・ツーリズムといった三つの視点をも とに，保護地域における地域住民のおかれている立場につ いて論じることにより, 現行の保護地域のあり方を批判的 に検討するとともに, 上記の枠組みに基づいて, 保護地域 をめぐる自然と人間の関係について分析する。第三に，今 後の保護地域管理のあり方について提言する。

\section{II. 自然と人間のとらえ方}

本章では，1. 節で自然と人間の関係をめぐる諸思想を取 り上げた上で，2. 節でこれらの思想を類型化するための枠 組みを提示する。

\section{1. 自然と人間の関係をめぐる思想}

はじめに，Ingold の自然に関するとらえ方（1996）を引 用しつつ, 筆者が本文で用いる自然について定義する。Ingold (1996：119）は，三つの異なる自然を例示している。 Ingold は, まず, 自然科学が研究対象としている「真のま まの」自然 ('really natural' nature) と, 社会人類学およ び文化人類学が研究対象としている「文化によって認知さ れた」自然 ('culturally perceived' nature) という二つの 自然を取り上げ，それらのいずれもが，自然を研究対象， 「客体」としてみていると指摘している。さらに, Ingold は, これら科学者が客体としてとらえている自然とは対置にあ る, ありのままの「自然, 人久が日常的に接している生活 の中にある自然をあげている。筆者が本文で用いる自然と は, Ingold が提示した三つの自然のうちの，ありのままの 「自然」を指すこととする。

次に, 環境社会学や環境倫理学などで論じられている, 自然と人間に関わる代表的な思想を取り上げることによ り，自然と人間の関係を論じる上での基本的な視点につい て示唆する。鳥越（1997：18-19；1989：18-20）は環境社 会学の分野で, 自然と人間の関係を,「近代技術主義」,「自 然環境主義」,「生活環境主義」の三つに分類している。「近 代技術主義」は，自然は手を加えなければ破壊されるもの であり，人間が近代技術という道具を用いて自然に接する からこそ環境破壊を免れることができ, 環境問題を解決す ることができると判断する立場である。「自然環境主義」と は, 人間の手の加わらない自然を一番望ましいとする立場 であり,力点は人間の生活ではなくて自然におかれている。
「生活環境主義」とは，人間を自然の中心にすえ，当該地域 に居住する居住者の立場から問題のあり方を考えようとい うものである。「生活環境主義」は，ローカルな生活者に注 目しているのに対して，「近代技術主義」と「自然環境主 義」はグローバルな視点からの自然保護に着目していると いえる。

井上 (2001) やNaess と Rothenberg (1989 (1997 訳)) は，ディープ・エコロジーの分野に抢いて，自然と人間と の関わりについて論じている。井上 (2001：5-6) は, ディープ・エコロジーの特徵を, シャロー・エコロジーと 対比しながら次のように説明している。現代社会の主流を なす環境保全の考え方は，政府の環境政策決定過程およ び，環境・開発に関わる国際会議や政府間交渉を重視し， 産業界に好まれる基本的枠組みを提供するものであり, シャロー・エコロジーと呼ばれるものである。シャロー・ エコロジーの究極的な目標は経済成長である。シャロー・ エコロジーは，現代の便利な文明をこのまま続けたとして も，自然環境に負荷をかけないような生活を実行すること により, 開発と保護の両立が実現されると主張する。新し い科学技術の開発, 生物資源を「科学的」に制御・管理 ・ 利用するバイオテクノロジーなどの「先端」科学・技術の 発展, 廃品回収 (リサイクル) などが, その例である。シャ ロー・エコロジーと同義の用語としてリフォーリズムがあ る。一方，ディープ・エコロジーのテーマは，人間を含め たすべての生命を生態系の中で関係論的に捉え，社会の環 境問題や矛盾へ問いかけをするとともに，生態系の中で自 己が具体的にどのように関わるのか，人間と人間の関係を どのようなものとして捉えるのかということである。以上 のように，シャロー・エコロジーが人間を中心とした持続 的資源管理を提唱しているのに対して，ディープ・エコロ ジーは，人間と人間以外を分け隔てることなく生命として 捉え，それを保護しょうというものであるといえる。

鬼頭 (1996：68-72), 河野 (1996：67-78) は, 既存の生 命中心主義の考え方として，「動物解放論」や「生態系 (工 コシステム) 保存論」をあげている。それによると，「動物 解放論」とは, 個々の動物の生存権の擁護を最大目標とし て，そのためには，正常なエコシステムの犠牲をも辞さな い。一方,「生態系保存論」は, 人間による他の生命の捕食 を最低限の生命維持のためのものに限って認めつつも, 生 態系に絶対的価值をおく。よって，人間が儀牲になること もあり得るとする。これら二つは，生態系を包括的に捉え， 生命を中心に据えるという点で共通した見方を提示してい るといえる。

Bookchin (1990 (1996 訳)) は, ソーシャル・エコロジー を提唱し，人間による自然の支配，従属性を批判し，その 状況から解放されるためには, 市場社会, 私有財産, 中央 集権的で官僚的な国家主義から脱却し，分権化された共同 体の思想, 自然と人間の関係が調和のとれた社会を構築し ていくことが必要であると説いた。これは，ローカルなレ ベルでの人間と生命との両立を重視した視点であると考え 
られる。

また，Pälsson（1996：67-76）は，自然と人間の関係を 「オリエンタリズム (Orientalism)」,「コミューナリズム (Communalism)」,「パターナリズム (Paternalism)」の三 つに分けた。「オリエンタリズム」は, 人間が自然の支配者 であり，自然は客体であることを提唱し，自然と人間の間 に本質的な破局を形作る。それは，支配，フロンティア， 拡大という言葉で典型的に代表され, 生産, 消費, 娛楽, 誇示といった多様な目的のために，環境を探査し，征服し， 開発する。環境の「管理」とは単に技術的問題であり, 専 門家と素人は区別される。「オリエンタリズム」では, 政府 が自然を国有化あるいは私有化し，独占することが，個人 的な欲望や環境の乱用を防ぐための唯一のオルタナティブ であると考えられている。「パターナリズム」は，人間が支 配者であり，素人と専門家が区別されている点では,「オリ エンタリズム」と類似しているが，人間が自然を開発する のではなく，保護するという点において異なる。つまり， 「パターナリズム」は, 環境主義的な見地からは, 人間は他 の種の構成員に調和すること, 動物王国の居住者や地球の 生態系に従う責任があるとしている。しかし，合理主義的 な立場ゆえに，人間と環境の関係に関して自然を崇拝する 傾向にあり，自然を人間の世界とはかけ離れたものとして 扱ってしまう。さらには,「オリエンタリズム」は客体主義 に陥るあまりに, 西洋的な言説によって, 地域の生産者と 欧米人を本質的に区別してしまう。「コミューナリズム」 は, 自然と社会の合理的な分断や区別, 確実性やモノログ の概念を排除し, 連続性や近接性を強調する。それは, 親 密で私的な関係, 個人的な関わりとして暗喻的に表現され るようなやりとりや，人間と自然の一般化された互酬性の うえに成り立っている。このように，「オリエンタリズム」 や「パターナリズム」は，人間への働きかけが異なる方向 (開発と保護) に作用するという違いはあるものの, 自然資 源を人間の利用のための存在と位置づけているのに対し て,「コミューナリズム」は自然と人間との調和を力説して いると考えられる。

Escobar（1999：6-13）は，自然を「資本主義的な自然 (capitalist nature)」, 「有機的な自然 (organic nature) 」, 「技術的な自然（technonature）」の三つに分けることによ り，人間と自然の関係を論じている。「資本主義的な自然」 では, 自然は, 人間にとって思いどおりに利用することが できる資源として位置づけられている。この考え方は，ポ ストルネッサンス・ヨーロッパの時代に出現し，18 世紀の 後半に, 資本主義および近代的認識様態の秩序の出現とと もに具象化された。これは, 専門家の知識に基づいて, 資 源と人口との合理的な管理形態を発達させることによっ て, 自然を統合してきた。さらに, 自然は, 労働を介した 商品としての生産物として扱われてきた。「有機的な自然」 では，自然と人間を二項対立的としてとらえてはいない。 これは, 生物世界, 人間世界, 超自然世界を区別する近代 的な思想とは異なり，これら三つの領域は密接に関連して
いることを主張する。文化人類学や生態学の研究が示唆す るように，第三世界の多くの村落共同体は，近代的な形態 とは全く異なる方法で自然を「構築」し，利用している。 それは，「ローカルな知恵に関わる人類学 (anthropology of local knowledge)」の領域に関わっている。「技術的な 自然」は，人間が改良し，手を加えた自然であり，ありの ままの自然を超越したものである。したがって, 生物は人 間によってコントロールされ，本来の自然は失われてしま い，生物のあり方そのものに関する新たな理念が創り出さ れる。ヒトゲノムプロジェクト,ナノバイオテクノロジー, クローニングなどの組換えDNA の進展が，「技術的な自 然」の顕著な例である。このように，「資本主義的な自然」 と「技術的な自然」はともに人間中心の開発指向の思想で あるのに対し，「有機的な自然」は自然と人間との調和に重 点をおいた思想であるといえる。

以上の議論より，自然と人間に関わる諸思想を体系的に 整理し，自然と人間の関係を明らかにするためには，(1)人 間による自然の支配，(2)人間以外あるいは人間を含めた生 命の支配，(3)自然と人間の調和，というた自然と人間との 様々な結びつきや，開発や保護といった人間の自然への接 し方に注目する必要があると考えられる。そこで，次節で は，まず，環境社会学や環境倫理学で論じられている自然 と人間の関係に関する一般概念を援用して，自然と人間の 関係をより詳細に把握する際に不可欠な要素を明らかにし た上で，本節で引用した各思想を包括しうる自然と人間を めぐる新たな枠組みを提示し, これらの諸思想を体系的に 整理する。

\section{2. 自然と人間の関係を捉えるための枠組み}

1970 年代に, アメリカの環境社会学において, Catton と Dunlap $(1978,1980)$ が, .「人間中心主義」の視点に立ち, 人間が自然界の中心であり自然を支配し利用するという， 既存の社会学の基盤となる「人間特例主義パラダイム (Human Exceptionalism Paradigm: HEP)」を否定し, 「新エコロジカル・パラダイム (New Ecological Paradigm:

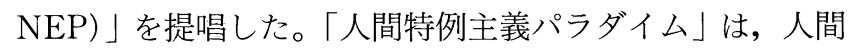
は動物とは異なり，生物遺伝的なものだけではなく，文化 的遺産をも継承すること，生物・物理的環境よりも，社会 的，文化的環境が人間に影響を及ぼすということ，人間文 化という技術や社会の進歩の成果を用いて, 社会問題が解 決できることを主張する。一方，「新エコロジカル・パラダ イム」は，人間には他の動物にはない文化や技術があった としても, 人間は地球の生態系に依存する生物種の一部に 過ぎないこと, 人間は, 生物・物理的環境のもとで生活し, 依存している以上，たとえ発明によって環境制約を超越し たようにみえたとしても，生態学的法則からは逃れられな いことを前提としている。

また，環境倫理学の分野では，環境問題に関わる自然と 人間の関係は，未来の世代を含めた人間の福祉をめざして 自然環境を維持管理しょうとする「人間中心主義」の思想 と, 人間以外の動植物, 生態系など自然物そのものに価值 
表 -1 . 自然と人間の関係

\begin{tabular}{|c|c|c|c|c|c|c|}
\hline & \multicolumn{3}{|c|}{ 生活者・ローカル・私 } & \multicolumn{3}{|c|}{ 専門家・グローバル・公 } \\
\hline & 人間中心 & 生命中心 & 共生 & 人間中心 & 生命中心 & 共生 \\
\hline 開発 & & & & $\begin{array}{l}\text { オリエンタリズム } \\
\text { 資本主義的な自然 } \\
\text { 技術的な自然 }\end{array}$ & & \\
\hline 保護 & & ディープ・エコロジー & & $\begin{array}{l}\text { 近代技術主義 } \\
\text { パターナリズム }\end{array}$ & $\begin{array}{l}\text { 動物解放論 } \\
\text { 生態系保存論 } \\
\text { 自然環境主義 }\end{array}$ & \\
\hline 持続的管理 & 生活環境主義 & & $\begin{array}{c}\text { コミューナリズム } \\
\text { 有機的な自然 } \\
\text { ソーシャル・エコロジー }\end{array}$ & $\begin{array}{c}\text { シャロー・エコロジー } \\
\text { リフォーリズム }\end{array}$ & & \\
\hline
\end{tabular}

や権利を認めようとする「生命（自然）中心主義」の思想 の二つに分けて自然と人間の関係が議論された（河野, 1996：60-61)。「人間中心主義」の思想では，自然は客体と みなされ，人間の都合のいいように自然を改良し，開発す る行為が含まれる。「人間中心主義」の思想は, 従来の自然 保護の概念も，経済至上主義による人間中心の自然生態系 の破壊を免れるため，自然を意図的に保護し，究極的には， 人間の存続，福祉をめざす保護に過ぎないと考えられてい る（鬼頭, 1996：120；河野, 1996：66）。

「人間中心主義」の概念は，Catton と Dunlap が提唱し た「人間特例主義パラダイム」とも共通するものである。 一方，「生命中心主義」では, 自然保護は自然そのものを保 護するための行為であり，それが人間の利益になるかどう かは問題にしない（鬼頭，1996：34）。自然と人間の関係を みる際，「人間中心主義」や「生命中心主義」のように人間 と人間以外のどちらが重要かという二項対立としてみる以 外に，地域に根ざした「自然と人間の共生（注 2)」の理念 も考慮に入れる必要がある。このような共生の理念は, Catton と Dunlap が提唱する「新エコロジカル・パラダイ ム」の理念を基盤としたものである（注 3 ）。

以上の議論から，自然と人間の関係を捉える軸として， 「人間中心」，「生命中心」，「共生」という三つの視座を提言 することとする。これらを改めて定義すると次のようにな る。「人間中心」とは，開発であれ保護であれ，人間が自然 を客体とみなし，人間にとって都合のいいように自然を改 良あるいは，利用・管理するような，人間の自然に対する 支配的な態度である。「生命中心」とは，人間にとって有益 かどうかに関わらず，動植物そのものの存在を優先的に考 える態度である。「共生」とは，人間とそれ以外とを相反す るものと捉えるのではなく，人間とそれ以外の生物が調和 し，すべての生物の間に密接なつながりがあるとする態度 である。これら，「人間中心」，「生命中心」，「共生」の理念 の対象が，グローバルな領域において有効なのか，あるい はローカルな領域において有効なのかを検討することは, それらの適応範囲を考える上で重要なことである。そこ で，生活に密着した私的な立場である「生活者・ローカル・ 私」と，私的な生活とはかけ離れた，特定の専門集団の間 で通用する公的な立場である「専門家・グローバル・公」
の二つの視点に分けて，これらの理念を検討する。さらに， 人間が自然に対してどのような影響を及ぼし，自然をどの ような状況へと誘導するのかを検討する。人間が自然にも たらす影響には，自然が人間の利益になるように，人間が 思い通りに自然を開拓・改良する場合（「自然の開発」），自 然に対する影響が及ばないように，人間が意図的に自然を 囲い込む場合 (「自然の保護」)，開発と保護が共生し，自然 の生態系の均衡が保持されている場合（「開発と保護が共 生する自然の持続可能な管理」）の三つが考えられる。

これら，「生活者あるいはローカルと専門家あるいはグ ローバル」，「開発と保護と持続的管理」，「人間中心と生命 中心と共生」という三つの軸から自然と人間との関係のマ トリクスを設定し，前節で議論した自然と人間の関係をめ ぐる諸思想をあてはめると表-1のようになる（注 4）。自然 と人間との関係を三つの軸から統括的に捉えた場合，既存 の論理的枠組みにみられるような一つの軸による整理では 捉えきれなかった側面を明確にすることができる（注 5)。 また，この表から，人間の自然への多様な接し方が，開発， 保護, 持続的管理といった自然への異なる影響を生み出す ことも明示された。

次に，これらの理念を類型化し，分類群ごとの概要を総 括的に説明する用語を定義する。自然と人間の関係の理念 を新たに類型化する際には，人間による自然への影響その ものではなく，その影響をもたらした人間の自然へのかか わり方に注目する。したがって, 開発と保護などのように, 最終的な現象が異なっていても，これらを誘引した背景が 同じであれば，同じ概念として分類する。つまり，表-1の 横軸の項目ごとに分類する。「人間中心」については,「ロー カルな生活者」そのものが中心となる「生活密着主義」, 「グローバル」な人々が中心となる「科学技術主義」，「ロー カル」な「生命」が中心となる「自然一体主義」，「グロー バル」な「生命」が中心となる「自然崇拝主義」に分ける こととする。また,「共生」はそもそも, グローバルレベル というよりも，むしろ，ローカルレベルに扔いて成り立つ 概念であり，共生が中心となる概念を「共生主義」とひと まとめにする。 


\section{III. 保護地域は誰のためのものか}

本章では，自然と人間の錯綜した関係が顕著にみられる 一事例として，保護地域管理を取り上げ，前章で構築した 枠組みを援用して，保護地域における自然と人間との関係 について分析する。

\section{1. アメリカの国立公園管理政策}

国立公園の起源は,「プリミティブなアメリカの光景を表 現」するものであり，「特定」の場所を日常生活の利用から 「隔離させる」ことを強調するものとして，アメリカで設定 され始めたことに遡る (Hales, 1989：140)。それ以降，国 立公園をはじめとした保護地域の歷史が本格的に展開され た。アメリカの国立公園の設立には, 保護と利用をめぐっ ての紆余曲折の歴史があった（伊藤，1997：113-120；上 岡, 2002 ; Runte, 1997)。アメリカではたぐいまれな景観 を保護するというモニュメンタリズムを基盤として, 経済 的に「無価値」な資源が国立公園として設定されてきた。 国立公園の管理は，イエローストーンにみられるように， 先住民を排除して，人が居住しない原生自然を保存すると いう理念に基づいて行われた。

とはいうものの，アメリカの国立公園管理政策は，保護 と利用という相反する概念を満たさなければならないとい うジレンマを抱えており，そのために，国立公園をめぐる 多くの論争が繰り広げられてきた。国立公園協会やシエ ラ・クラブなどの市民による自然保護団体は，自然は損な われることなく保護するべきであるという主張をした。一 方，政府は，国立公園内でのダムの建設，国立公園周辺で の鉄道用地の開発, 公園内での電線設置, 道路建設など, 国立公園を利用あるいは開放するという政策を打ち出すこ とが多かった。さらに, 公園政策にとって,レクリエーショ ンのためのリゾート開発は重要な政策であった。市民は, 国立公園間を結ぶ鉄道や自動車を利用して国立公園を訪れ た。第二次大戦中には，戦争協力という名のもと，国立公 園は森林伐採，牧畜，鉱山開発のために開放された。この ように，アメリカの国立公園管理は，必ずしも生態系保全 という目標を達成できたわけではなかった。

\section{2.「自然保護」としての保護地域}

生物学者などの自然保護主義者は，人間による利用は熱 帯林の生態の破壊を招くとして，地域住民をやり玉にあ げ，地域住民と生物多様性の共生は不可能であると主張す る (Brandon et al., 1998; Kramer and Schaik, 1997; Schaik et al., 1997, 2002; Terborgh, 1999; Terborgh and Peres, 2002; Terborgh and Schaik, 2002)。自然保護主義 者は，現実に世界各国の熱帯林や保護地域で発生している 狩猟，伐採，牧畜などによる森林破壊の現状を並べ，隔離 された自然としての保護地域設定の妥当性を主張する (Bruner et al., 2001; Terberg and Peres, 2002)。例えば, Bruner ら（2001）は，世界中の 22 力国, 93 力所の保護地 域に扔いて，人間の活動が生態系に及ぼす影響についての 調査を行った。その結果, 法的施行・境界線の確立・地域
共同体への直接的な代償などの国立公園管理が，生態系の 破壊を阻止するのに効果的であることを実証した。自然保 護主義者によると,「保護地域が設定される以前から，人び とは数世紀にもわたってその地域に居住し続けてきたので あり，環境を劇的には破壞しない」という議論は詭弁でし かなく，実際には，規模の大小に関わらず人口増加と近代 技術の獲得に伴って，人間の自然への影響が生じるという (Kramer and Schaik, 1997; Schaik et al., 2002)。自然保 護主義者は，保護と利用が両立しうる持続的利用というパ ラダイムは一種のユートピアに過ぎず，貴重な生物資源を 保護するためには，自然保護主義者であるべきだと主張す る。保護という視点からは，森林に居住する人々は自然に 敵対する存在として君臨するものであり，その正当性を認 める余地はない。自然保護主義者は，地域住民の資源から の隔離を目的とした移住が，国立公園内での人間の影響を 軽減する最も直接的で効果的な方法であると考えている (Terborgh and Peres, 2002: 312; Redford et al., 1998: 463)。

また，国立公園をはじめとしたスタッフは，生物学的な 知識は豊富であるが，社会学的な知識に関する教育をほと んど受けていない（Hough, 1988: 130）。彼ら，特権階級で ある南のエリートは, 欧米の大学への留学によって先進国 が発展途上国に強要する保護地域の理念を教え込まれ, 先 進国と発展途上国とでは社会環境や生態環境が異なること を忘却し, 欧米から移植された保護地域管理の理念を抵抗 なく受け入れ，それを実践する。

\section{3.「ブランド」としての保護地域}

世界中の資源が破壊され，稀少生物が存亡の危機にたた された 1980 年代頃から, 開発と利用の両立を目指した「持 続可能な開発」の理念に基づいた ICDP (Integrated conservation and development project：統合的な保護と開 発）（注 6）が実施されるようになった。発展途上国に扔け る保護地域政策も ICDP に積極的に応じている。しかし， 保護地域政策は, 単に理念への共感に基づいているだけで はなく，政策を先進国の自然保護主義の思想に合致させ， 先進国世論の賛同を得ることによって，二国間援助，国際 機関，国際 NGO などからの資金を獲得するためにも利用 されている。実際, プロジェクトを行う際に, 多くのドナー が政府のカウンターパートに対して支払う契約金は, 政府 の保護活動資金を大幅に増加させるのに貢献してきた (Wells et al., 1999: 38)。これらの世界銀行や国連による 援助や, USAID (U.S. Agency for International Development), GTZ (German Technical Cooperation), EU (Europe Union) などの二国間協定による援助を目的とし たプロジェクトを通じて, 発展途上国は多くの外貨資金獲 得に成功した (Dourojeanni, 2002: 326; Schelhas et al., 2001: xxii; Spergel, 2002: 374)。また, WWF, The Nature Conservancy や Conservation International は, 発展途上 国の保護地域や保全プロジェクトを支援するために，毎 年, 数千または数億ドルもの貢献をしている (Spergel, 
2002: 373)。例えば，インドネシアの場合，1980 年代から 開始された ICDP は，その対象地が 1997 年には，850万 ha, インドネシアの保護地域全体の $40 \%$ を占めるまでにな り，外国のドナーからの資金援助は 130 百万ドルにも達し ており, 今後さらに, 200 百万ドルの国際的なローンや無償 資金が組まれようとしている（Wells et al., 1999: 13）。ま た，保護地域の中でも，特に国立公園は，比較的多くの政 府資金を得ることができるために，政府は，いくつかの保 護地域を国立公園に転換しようと目論んでいる（Schelhas et al., 2001: 38)。

\section{4. エコ・ツーリズムの役割}

1970 年代の世界的な環境意識の高まりとともに, 発展途 上国の人びとにとって重要なことは経済的価值であり，保 護は経済的発展を通じて促進されるべきであるという考え が広まり，ICDP の一環として，エコ・ツーリズムに関する プロジェクトが行われ始めた(注 7) (Schelhas et al., 2001: xxii)。元来, 観光産業は, 自動車や電気機器の製造業, 農 業といった他の産業と比較しても，より多くの外貨を生み 出す世界で最も大きな産業であり, 雇用の創出も可能にす る (Harrison, 1992; IUCN, 2002)。また，発展途上国の観 光産業は, 国内総生産の $50 \%$ 以上を占める重要なものであ る (Lindberg, 1991)。その中でも，特に，エコ・ツーリズ ムは，最も成長の著しい部門であり，年間成長率は 10 15\%と見積もられている (Maikhuri et al., 2000: 334)。こ のように，エコ・ツーリズムは，「開発へのパスポート」 (Maikhuri et al., 2000: 334)，すなわち，「外国からの多く の旅行者を呼び込み, 多くの外貨獲得が可能な産業」とし て地域発展に貢献し, 結果的には国全体の経済成長をも促 すことができる，国の発展にとって不可欠な要素となって いる。

エコ・ツーリズムの特徵は様久な言葉で表現される。自 然保護を基盤として考えるならば，「持続的なツーリズ ム」,「持続的に管理されたツーリズム」，「環境に責任のあ るツーリズム」，「保全ツーリズム」と表現されるし，また， 教育ということを重視するならば，「環境教育ツーリズ ム」,「科学ツーリズム」などといわれる (Blount, 2001: 504-506)。また, Boo (1991 (1992 訳)：1）は, エコ・ツー リズムを，「(1)保護地域のための資金を生み出し，(2)地域社 会の雇用機会を創出し，(3)環境教育を提供することによっ て, 自然保護に貢献するような自然志向型の観光 (ツーリ ズム）である」と定義している。また，マスツーリズムな ぞ, 他の観光産業とは異なり, エコ・ツーリズムの特徴は, 参加する集団のサイズも小さく，野生動物や地域住民との 触れ合いや，動植物などの地域資源の保全への意識が求め られている (Goodwin, 1996; IUCN, 2002; King and Stewart 1996; Nelson, 1994: 248-249)。さらに，エコ・ツー リズムは，地域住民が，インタープリターやガイドとして 地域の資源を紹介したり, 計画段階におけるアドバイザー として参加したりすることによって，住民の参加・協力に よる運営を目指している（エコツーリズム推進協議会,
1999：27-28)。エコ・ツーリズムは，保護地域の周辺や内 部にもともと居住していた地域住民が，その活動によって 負の影響ではなく，正の影響を受けることが期待されてい るのである。

\section{5. 地域住民にとっての保護地域}

以上の議論をもとに, 地域住民の視点から保護地域の実 態について批判的に検討し, 地域住民にとっての保護地域 のあるべき姿について論じてみたい。Wells らは,インドネ シアの例をあげて, 保護地域の現状について次のように説 明している。

「保護地域内で，村人が木材を伐採すること，野生動物を 狩猟すること，作物を栽培することは，インドネシアの多 くの保護地域が直面している主たる脅威ではない。それら 以上に保護地域を脅かす原因は数多く存在する。例えば, 保護地域内での伐採, 採掘や野生生物の密猟といった外部 者による違法行為, 保護地域の周辺の森林での粗悪な伐採 事業，保全と相容れない森林の転換，違法行為を容易にす る保護地域内および周辺の劣悪な道路, 保護地域周辺の大 規模な都市化によってもたらされる資源需要の拡大, 移住 プロジェクトなどがあげられる」(Wells et al., 1999: 34)。

保護か利用かをめぐって森林破壊の原因を探る際に，た だ単に表面的に現れる因果関係をみるだけではなく，国の 森林政策との関わりの中で，根本的な森林生態系の破壊の 原因を探る必要がある。地域住民は森林破壊の主犯という よりは，むしろ，生物多様性保全というグローバルな利益 が追求される保護地域によって，自らが長年利用してきた 資源へのアクセスを一方的に禁じられた犠牲者とみなすこ ともできる。日常的な必需品を全面的に森林資源に依存し ている地域住民は，保護地域から経済的利益を得られない のであれば，保護にかまっている余裕はない。自然生態系 の保護のみを重視した保護地域の内部や周辺に住む人久 は，政治的に権力をもち，かつ利害関係に関心をもつグ ループからの圧力によって，文化的にも社会的にも徐々に 辺境へと追いやられてしまう（Marks, 1991; Taconni, 2000)。多くの熱帯地域に扔いて，保護地域の周辺または, 将来保護地域に指定される地域の周辺には，地域住民がい るという事実を考慮すると, 自然保護主義者は, 必然的に, 地域共同体を崩壊へと追いやることになる。

また，保護地域は，間接的にも地域住民の生活を劦かす。 保護された野生動物が地域住民の農業などに被害を及ぼす こともある (Cauhoun, 1991; Hoare and Johan, 1999; Karanth and Madhusudan, 2002; Schelhas, 1991: 326-327)。しかし，自然保護主義のもとでは，地域住民に は口を挾む余地は与えられない。さらに，研究者は，地域 住民の知の助けを借りながら，生物学的，社会経済的デー 夕を収集するフィールドとして保護地域を活用する。研究 者によって，地域住民の知的所有権はいとも簡単に侵害さ れてしまうこともある (Brush, 1996; Dove, 1996; Laird, 2002）。地域住民には何の成果も還元されないまま，地域住 民の知が踏みにじられることも少なくない。 
保護地域管理には，多額の外部資金が投入されているに も関わらず，政府による不的確な予算の運営は後を絶たず， 政府の責任感は相変わらず欠如している。政府が, 独自に プロジェクトの成果を継続させ，保護地域を効果的に管理 することは困難である。政府が保護地域を設定するという 名目で，外部からの資金を得ているのとは対照的に，地域 住民は何の見返りもなく, 保護地域の資源の保護を強要さ れる。保護地域に投入される多額の外貨とは対照的に, 地 域住民は，多くの場合，村での森林警備員あるいは保護地 域の違法伐採労働者として, 安い賃金でかり出される。

エコ・ツーリズムの目的の一つは，地域住民が様々な形 で参加することによって, 地域住民の経済的水準を向上さ せることである。果たして，エコ・ツーリズムには地域経 済を充分に活性化させるような影響力があるのだろうか。 Terborgh と Peres (2002: 314-315) は, 地域住民が農業や 自然資源に依存した慣習的な生業形態を捨て去り，ボート ドライバー，料理人，メカニックとしてエコ・ツーリズム に携わることは，国立公園への人的影響を軽減する上でも 有益であると指摘している。しかし，地域住民が行うこと ができる仕事は, 宿泊施設や売店など, 旅行産業の中でも 最も賃金が低い業種に限られているために，エコ・ッーリ ズムの地域への経済的貢献はごく僅かであり, 結果的に, 外部の労働者やッーリストと地域住民との間での, 豊かさ や社会経済的地位の不均衡が増長される (Blount, 2001: 509)。エコ・ツーリズムを運営している権力をもった高級 官僚が利益を独占している一方, 権力のない地域の人び と，本来，エコ・ツーリズムによって利益をもたらされる はずの人びとに利益が均等に分配されるシステムは十分に 構築されてはいない。

さらに，Terborgh と Peres (2002: 314-315) は，国立公 園における，政府主導の政策の一環としてのエコ・ツーリ ズムのみが，一時的であるにせよ，資源を破壊することの ない唯一の持続可能な開発モデルであると指摘している。 このような考え方は，地域住民こそが，自然資源を破壊す る主犯であるいう口実の下，地域住民を「生きた博物館」 (Terborgh and Peres, 2002: 314) として封じ込めてしま うやり方である。地域住民は自然に負の影響を与えるやっ かいものであり，「見せ物」である客体として扱われる。そ の結果，エコ・ツーリズムは，地域住民の「商品化」また は「博物館化」を促す。国立公園を訪れるツーリストは, 真の自然を満契しているのではなく，このような博物館の 陳列を見物しているにすぎない (King and Stewart, 1996: 297)。経済的に豊かな先進国の人びとは，エコ・ツーリズ ムによって，保護地域という人為的に「切り取られた自然」 を満喫する一方, 地域住民は，保護地域における「枠には めこまれた材料」としてエコ・ツーリズムを盛り上げる。

果たして，これは地域住民が望んでいる生き方なのであ ろうか。エコ・ツーリズムは，一時的には，地域住民を国 立公園内あるいは保護地域内の自然資源に依存した生業か ら，エコ・ツーリズム関連事業へと移行させ，ある程度の
自然破壊を免れることはできるかもしれない。しかし，エ コ・ツーリズムの影で，地域住民の資源へのアクセスが制 限され, 慣習的な生業活動が放棄され, 経済的, 生態的, 文化的な負の影響がもたらされる（Blount, 2001; McNeely; 1989: 509; Rai and Sundriyal, 1997)。さらに，エ コ・ツーリズムに参加する地域住民は，今までの自然と共 存した生活スタイルを興味本位で見物され，時には剝奪さ れ，自らのアイデンティティを失う可能性すらある。地域 住民は, 宿泊施設や売店の経営者や従業員やッアーガイ ド，あるいは保護地域管理官としてッーリストにサービス を提供する存在であり(伊藤, 1997 : 16), また, 外部から の政府関係者, 研究者, 自然保護団体が一方的に啓蒙する 対象となってしまう。

この文脈においては，地域住民は，活動の主体ではなく， 開発という「外部の論理」(菊地，1999：139）を押しつけ られた客体である (注 8)。地域経済の活性化や雇用の創出 も重要な課題ではあるが，それ以前の地域固有の論理を尊 重するという姿勢も欠かしてはならない。ただ単に, 経済 的利益をもたらす手段として国立公園をみるべきではない のだ (Davenport et al., 2002: 280)。

このように，自然保護主義の思想に基づいた保護地域が 生物多様性の豊かな熱帯林を覆い尽くすことによって,「文 化的植民地主義」（注 9）は浸透していく。環境破壊が，国 内に扔引権力の強い中央のものによる, 権力の弱い周辺 部の支配抢よび，北の富める国による，南の貧しい国の資 源をめぐる支配という二つの構図のもと引き起こされる社 会問題である（原田，2003 a ; 横田，2003）のと同じよう に，保護地域管理も，強者による，弱者を排除した独占的 な資源の支配という構図の上に成り立っているのである。

\section{6. 資源をめぐる利害関係者の対立の構図}

純粋に自然保護を目的とした自然保護主義者にとって， 自然資源を利用する地域住民を排除することは，生物多様 性保全にとって重要なことである。また，保護地域を管理 する行政官にとっては, 生態的, 生物的な環境保全という 純然たる論理だけではなく，生物多様性保全を目的とした 保護地域設定やエコ・ツーリズムによる外貨獲得も，保護 地域管理の大きな動機づけとなる。このように，自然保護 主義者や行政官の保護地域への接し方は，専門家あるい は,グローバルな視点からの保護に基づいたものである (「自然崇帱主義」)。一方, 地域住民は, 保護地域を保護す る対象としてではなく，自分たちの身の周りにある日常生 活に利用する資源としてみなしている。保護地域からの影 響を受けつつも，保護地域という枠にとらわれない生き方 をしてきた彼らの自然への接し方は，生活者・ローカルの 視点であり，持続可能な資源管理を行っていこうとするも のである(「生活密着主義」)。また, 保護地域は, 一部の行 政官や，外部者によって，違法森林伐採などの開発の影響 も受けている(「科学技術主義」)。

このように，保護地域の資源をめぐる地域住民と政府の 関係は，基本的には，生活者としての人間が中心となる 
「生活密着主義」と，専門家による生命が中心となる「自然 崇拝主義」という，相容れない分類群の間の対立を基盤と しており，このような状況が保護地域管理を困難にしてき た。さらに，保護地域には，「科学技術主義」に基づいた保 護の理念とは相反するグローバルな開発の波も押し寄せて おり，保護に携わる行政官の信念が確固としたものでなけ れば, 保護の理念は, 外部からの圧力により, 開発の理念 に容易に置き換わる危険性を常に秘めている。つまり,「科 学技術主義」と「自然崇择主義」は, 表裏一体の関係にあ るといえる。

\section{IV. 保護地域管理の課題}

今までに, 野生動植物と地域住民が共生できる方法が模 索されてきた（秋道，1999; Bidol and Crowfoot, 1991; Escobar, 1996; Hales, 1989; Hough, 1988; 市川, 1994; 鬼 頭, 1996; McNeely, 1989; Nepal and Weber, 1995; Salafsky and Wollenberg, 2000; Schwartzman et al., 2000; Tacconi, 2000; Tisdell, 1995)。そこでは, 文化と自然のむ すびつきの多様性 (秋道, 1999：12), 保護と利用の両立を はかろうとする自然の「持続的利用」の理念 (市川, 1994 ： 198), 持続的開発と生物多様性の言説 (Escobar, 1996: 53) が議論されてきた。自然保護に第一のプライオリティがあ るというわけではなく, ましてや, 自然と人間は切り離し て考えられるものでもない。両者が長い年月をかけて歩ん できた「共生」の歴史を放棄するのではなく，その延長と して, 新しい保護地域の概念を適応していかなければなら ない。

これを実現するためには, 地域住民および政府の双方が 保護と利用の両立にむけて，お互いに歩み寄る必要がある と考えられる。政府は, 今までの中央集権的で, 住民を完 全に排除した保護地域管理を改め, 保護地域管理の部分的 な地方分権化を実施し，資源の近くに住む人々とも積極的 に協議し, 政府と地域住民の双方が納得した上で, 地域住 民にも保護地域管理の責任を委譲することが重要である。 生物多様性保全や保護地域は，外国からの援助やドナーと のつながりが非常に強く, 空口としての中央政府の役割も 重要となる。したがって, 現場レべルでの管理は, 地方政 府と住民が協働で行い, 保護地域に関わる予算執行や人員 配置, 管理のモニタリングなど，全体の統制は今まで通り に中央政府が行うというのが一つの方法として考えられ る。

また, 地方分権化では, 保護地域管理をめぐって, 地域 住民は直接政府との話し合いや交涉のプロセスに参加する ことが重要である。その際には, 地域共同体内の個々人が 保護地域管理についてばらばらの意見を保持していては, 政府との交渉や議論にまとまりがつかない。そこで, 保護 地域管理に向けて, 住民を組織化することによって, 政府 との交渉をする空口は，個々人ではなく住民組織に委ねる ことを提言したい（注 10）。これによって, 今までは, 保護 地域の存在によって, 自分たちの生活が脅かされているに
も関わらず，発言する機会が得られなかった人々が，一致 団結して政府と直接交涉することが可能となると考えられ る(注 11)。

政府自身は，自らの政策を的確に改定するほど現場の状 況に精通しているわけではないし，また，それを実施する のに十分な人員を備えているわけでもない。また，多くの 場合，地域共同体にとって，政府と対等に議論できるほど の十分な住民組織化を独自に形成するのは困難である。そ こで,これら両者の乘離を埋めるために, 政府の政策に対 して提言をし，地域住民の住民組織化を支援しつつ，両者 を調停できる国際 NGO やローカル NGO といった第三者 あるいは，外部者の役割が不可欠であると考えられる。政 府，地域住民，第三者の間の連携があってはじめて，自然 資源をめぐる「共生主義」が実現可能となるのである。

本稿の執筆にあたっては, 東京大学大学院農学生命科学 研究科の永田 信教授, 井上 真教授, 国際農林水産業研 究センターの横田康裕氏および, 査読者の方々から多くの 有益なコメントを頂いた。心より感謝を申し上げます。

\section{引用文献}

秋道智彌 (1999) 自然はだれのものか一開発と保護のパラダイム再 考.（自然はだれのものか一「コモンズの悲劇」を超えて. 秋道智 彌編, $234 \mathrm{pp}$, 昭和堂, 京都). 4-20.

Beltran, J. (2000) Indigenous and traditional peoples and protected areas: principles, guidelines and case studies. 133 pp, IUCN, Gland, Swizerland.

Bidol, P. and Crowfoot, J.E. (1991) Toward an interactive process for siting national parks in developing nations. In Resident people and national parks: social dilemmas and strategies in international conservation. West, P.C. and Brechin, S.R. (eds.), $443 \mathrm{pp}$, the University of Arizona Press, Tuscon, 283-300.

Blount, B.G. (2001) Indigenous peoples and the uses and abuses of ecotourism. In On biocultural diversity: linking language, knowledge, and the environment. Maffi, L. (ed.), $578 \mathrm{pp}$, the Smithsonian Institution Press, Washington, D.C. and London, 503-516.

Boo, E. (1991) Planning for ecotourism, Parks 2(3) (薄木三生訳 (1992）エコ・ツーリズム計画. 国立公園 501：2-7).

Bookchin, M. (1990) Remarking society: pathway to a green future. $222 \mathrm{pp}$, Black Rose Books, Montreal and New York （藤堂麻理子・戸田 清・萩原なつ子訳（1996）エコロジーと社 会. $295 \mathrm{pp}$, 白水社, 東京).

Brandon, K., Redford, K.H., and Sanderson, S. E. (1998) Introduction. In Parks in peril: people, politics, and protected areas. Brandon K., Redford, K.H., and Sanderson, S.E. (eds.), 519 pp, Island Press, Washington, D.C., 1-26.

Bruner, A.G., Gullison, R.E., Rice, R.E., and da Fonseca, G.A.B. (2001) Effectiveness of parks in protecting tropical biodiversity. Science $291: 125-128$.

Brush, S.B. (1996) Whose knowledge, whose genes, whose rights? In Valuing local knowledge: indigenous people and intellectual property rights. Brush, S.B. and Stabinsky, D. (eds.), 337 pp, Island Press, Washington, D.C., 1-24.

Catton, W.R., Jr. and Dunlap, R.E. (1978) Environmental sociology: a new paradigm. Am. Sociol. 13 (February) : 41-49.

Catton, W. R., Jr. and Dunlap, R. E. (1980) A new ecological paradigm for post-exuberant sociology. Am. Behav. Sci. 24 (September/October) : 15-47. 
Cauhoun, J.B. (1991) The plight of the Ik. In Resident peoples and national parks: social dilemmas and strategies in international conservation. West, P.C. and Brechin, S.R. (eds.), 443 pp, University of Arizona Press, Tuscon, 55-60.

Davenport, L., Brockelman, W.Y., Wright, P.C., Ruf, K., and del Valle, F.B.R. (2002) Ecotourism tools for parks. In Making parks work: strategies for preserving tropical nature. Terborgh, J., van Schaik, C., Davenport, L., and Rao, M. (eds.), Island Press, Washington, D.C., 279-306.

Dourojeanni, M.J. (2002) Political will for establishing and managing parks. In Making parks work: strategies for preserving tropical nature. Terborgh, J., van Schaik, C., Davenport, L., and Rao, M. (eds.), Island Press, Washington, D.C., 320-334.

Dove, M.R. (1996) Center, periphery, and biodiversity: a paradox of governance and a developmental challenge. In Valuing local knowledge: indigenous people and intellectual property rights. Brush, S.B. and Stabinsky, D. (eds.), Island Press, Washington, D.C., 41-67.

エコツーリズム推進協議会（1999）エコツーリズムの世紀へ. 319 $\mathrm{pp}$, エコツーリズム推進協議会, 東京.

Elmandjra, M. (1996) La decoloniasation culturelle: derfi majeure du 21 eme siecle. editions Walli. 341 pp. (仲正昌樹訳 (2002) 文 化的脱植民地化一国際政治のコロニアルな構造をめぐって. 198 $\mathrm{pp}$, 御茶の水書房, 東京) .

Escobar, A. (1996) Constructing nature: elements for a poststructural political ecology. In Liberation ecologies: environment, development, social movements. Peet, R. and Watts, M. (eds.), 273 pp, Routledge, New York, 46-68.

Escobar A. (1999) After nature: steps to an antiessentialist political ecology. Curr. Anthropol. 40 (1) : 1-30.

Goodwin, H. (1996) In pursuit of ecotourism. Biodivers. Conserv. 5: $277-291$.

Hales, D. (1989) Changing concepts of national parks. In Conservation for the twenty-first century. Western, D. and Pearl, M. (eds.), 365 pp, Oxford University Press, New York and Oxford, 139-144.

原田一宏（2001）熱帯林の保護地域と地域住民（コモンズの社会学 一森・川・海の資源共同管理を考える. 井上 真・宮内泰介編, $251 \mathrm{pp}$, 新曜社, 東京) . 190-211.

Harada, K. (2003) Policy of protected areas and local use of forest resources in Indonesia: a case study of a national park in West Java. In People and forest in Southeast Asia, Fareast Russia, and Japan: forest policy and local reality. Inoue, M. and Isozaki, H. (eds.), Kluwer Academic Publisher, Dordrecht, 231-247.

原田一宏（2003 a）保護地域に求められているもの一保護地域は環 境破壊を防ぐための新たなパラダイムとなり得るのか一。林業 経済 56(1)：15-25.

原田一宏（2003 b）保護地域に求められるローカルな視点.（アジア 環境白書 2003/04. 日本環境会議編, $464 \mathrm{pp}$, 東洋経済新報社, 東京). 334-339.

原田一宏 $(2003 \mathrm{c}$ ) 保護地域の自然資源をめぐる紛争管理一政府と 地域住民の対立をとらえるためのフレームワーク一．林業経済 研究 49(2)：35-43.

Harrison, D. (1992) Tourism and the less developed countries. 186 pp, Halsted Press, New York and Toronto.

Hoare, R.E. and Johan, T.D.T. (1999) Coexistence between people and elephants in African Savannas. Conserv. Biol. 13: 633-639.

Hough, J.L. (1988) Obstacles to effective management of conflicts between national parks and surrounding human communities in developing countries. Environ. Conserv. 15:129-136.

百村帝彦（2003）保護地域における森林管理一ラオス南部・サワンナ ケート県の事例。（アジアにおける森林の消失と保全. 井上 真 編, $324 \mathrm{pp}$, 中央法規, 東京).219-236.

市川光雄（1994）漁撈活動の持続を支える社会機構.（資源への文化
適応一自然との共存のエコロジー一(講座地球に生きる 3 )。大 塚柳太郎他編, $304 \mathrm{pp}$, 雄山閣, 東京). 195-218.

Ingold, T. (1996) Hunting and gathering as ways of perceiving the environment. In Redefining nature: ecology, culture and domestication. Ellen, R. and Fukui, K. (eds.), Oxford International Publishers Ltd., Oxford, 117-155.

井上有一 (2001) 序 深いエコロジー運動とは何かーディープ・エコ ロジー運動の誕生と展開. (ディープ・エコロジー一生き方から考 える環境の思想.アラン・ドレングソン・井上有一編, $297 \mathrm{pp}$, 昭 和堂, 京都) . 1-27.

伊藤太一 (1997) エコツーリズムのジレンマ. 森林科学 21: 16-22.

IUCN (1994) Guidelines for protected area management categories. $261 \mathrm{pp}$, CNPPA with the assistance of WCMC, IUCN, Gland and Cambridge.

IUCN (2002) Guidelines for tourism in parks and protected areas of East Asia. 114 pp, http://www. ahs. uwaterloo. ca/ eagles/ East Asia. pdf

Karanth, K.U. and Madhusudan, M.D. (2002) Mitigating humanwildlife conflicts in Southern Asia. In Making parks work: strategies for preserving tropical nature. Terborgh, J., van Schaik, C., Davenport, L., and Rao, M. (eds.), Island Press, Washington, D.C., 250-264.

上岡克己（2002）アメリカの国立公園一自然保護運動と公園政策一. $221 \mathrm{pp}$, 築地書館, 東京.

King, D.A. and Stewart, W.P. (1996) Ecotourism and commodification: protecting people and places. Biodivers. Conserv. $5: 293-305$.

菊地直樹（1999）エコ・ツーリズムの分析視角に向けて一エコ・ツー リズムに扔ける「地域住民」と「自然」の検討を通して一。環境 社会学研究 $5: 136-151$.

鬼頭秀一（1996）自然保護を問いなおす一環境倫理とネットワーク． $254 \mathrm{pp}$, 筑摩書房, 東京.

鬼頭秀一 (2002) 環境倫理と公私問題。(地球環境と公共性. 佐々木 毅・金 泰昌編, $346 \mathrm{pp}$, 東京大学出版会, 東京).221-254。

河野勝彦（1996）環境倫理の哲学的論点.（環境哲学の探求. 尾関周 二編, $255 \mathrm{pp}$, 大月書店, 東京). 59-87.

Kramer, R. and Schaik, C.P. (1997) Preservation paradigms and tropical rain forests. In Last stand: protected areas and the defense of tropical diversity. Kramer, R., van Schaik, C., and Johnson, J., (eds.), 242 pp, Oxford University Press, New York, 3-14.

Laird, S. (2002) Biodiversity and traditional knowledge: equtable partnerships in practice. 504 pp, Earthscan, London.

Lindberg, K. (1991) Policies for maximizing nature tourism's ecological and economic benefits. 37 pp, World Resource Institute, Washington, D.C.

Maikhuri R.K., Rana, U., Rao, K.S., Nautiyal, S., and Saxena, K. G. (2000) Promoting ecotourism in the buffer zone areas of Nanda Devi Bisphere Reserve: an option to resolve peoplepolicy conflict. Int. J. Sus. Dev. World Ecol. $7: 333-342$.

Marks, S.A. (1991) Some reflections on participation and Comanagement from Zambia's Luangwa Valley. In Resident peoples and national parks: social dilemmas and strategies in international conservation. West, P.C. and Brechin, S.R. (eds.), University of Arizona Press, Tucson, 346-358.

McNeely, J.A. (1989) Protected areas and human ecology: how national parks can contribute to sustaining societies of the twenty-first century. In Conservation for the twenty-first century. Western, D. and Pearl, M. (eds.), 365 pp, Oxford University Press, New York and Oxford, 150-157.

Naess, A. and Rothenberg, D. (1989) Ecology, community and lifestyle. 223 pp, Cambridge University Press, Cambridge. (斎 藤直輔・開 竜美訳（1997）ディープ・エコロジーとは何か一エ コロジー・共同体ライフスタイルー。ヴァリエ叢書. $355 \mathrm{pp}$, 文 化書房博文社, 東京) 。

Nash, D. (1989) Tourism as a form of imperialism. In Host and guests: the anthropology of tourism. Smith, V. (eds.), $341 \mathrm{pp}$, 
University of Pennsylvania Press, Philadelphia, 33-48.

Nelson, J.G. (1994) The spread of ecotourism: some planning implications. Environ. Conserv. $21: 248-255$.

Nepal, S.K. and Weber, K.E. (1995) Managing resources and resolving conflicts: national parks and local people. Int. J. Sus. Dev. World Ecol. 2 : 11-25.

尾関周二（1995）環境問題と人間-自然観.（環境哲学の探究. 尾崎周 二編, $262 \mathrm{pp}$, 大月書店, 東京). 19-58.

Pälsson, G. (1996) Human-environmental relations: orientalism, paternalism, and communalism. In Nature and society: anthropological perspectives. Descola, P. and Pälsson, G. (eds.), 310 pp, Routledge, New York, 63-81.

Rai, S.C. and Sundriyal, R.C. (1997) Tourism and biodiversity conservation: the Sikkim Himakaya. Ambio 26 : 235-242.

Redford, K., Brandon K., and Sanderson, S. (1998) Holding ground. In Parks in peril: people, politics, and protected areas. Brandon, K., Redford, K.H., and Sanderson, S.E. (eds.), 519 pp, Island Press, Washington, D.C., 455-463.

Runte, A. (1997) National parks: the American experience. 335 pp, University of Nebrask Press, Lincoln and London.

Salafsky, N. and Wollenberg, E. (2000) Linking livelihoods and conservation: a conceptual framework and scale for assessing the integration of human needs and biodiversity. World Dev. $28: 1421-1438$.

佐藤 寛（2004）住民組織化をなぜ問題にするのか。（援助と住民組

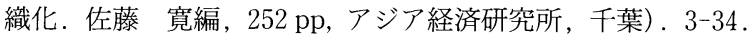

佐藤 仁 (2002) 稀少資源のポリティックス：タイ農村に見る開発 と環境のはざま， $254 \mathrm{pp}$, 東京大学出版会, 東京.

Schaik, C.V., Terborgh, J., and Dugelby, B. (1997) The silent crisis: the state of rain forest nature preserves. In Last stand: protected areas and the defense of tropical diversity. Kramer, R., van Schaik, C., and Johnson, J. (eds.), 242 pp, Oxford University Press, New York, 3-14.

Schaik, C.V., Terborgh, J., Davenport, L., and Rao, M. (2002) Making parks work: past, present, and future. In Making parks work: strategies for preserving tropical nature. Terborgh, J., van Schaik, C., Davenport, L., and Rao, M. (eds.), Island Press, Washington, D.C., 468-481.

Schelhas, J. (1991) A metholodogy for assessment of external issues facing national parks, with an application in Costa Rica. Environ. Conserv. 18:323-330.

Schelhas, J., Buck, L.E., and Geisler, C.C. (2001) Introduction: the challenge of adaptive collaborative management. In Biological diversity: balancing interests through adaptive collaborative management. Buck, L.E., Geisler, C.C., Schelhas, J., and Wollenberg, E. (eds.), 465 pp, CRC Press, Boca Raton, xixxxxv.

Schwartzman, S., Moreira, A., and Nepstad, A. D. (2000) Rethinking tropical forest conservation: perils in parks. Conserv. Biol. $14: 1351-1357$.

Spergel, B. (2002) Financing protected areas. In Making parks work: strategies for preserving tropical nature. Terborgh, J., van Schaik, C., Davenport, L., and Rao, M. (eds.), Island Press, Washington, D.C., 364-382.

Tacconi, L. (2000) Biodiversity and ecological economics: participation, values and resource management. 254 pp, Earthscan Publications Ltd., London and Sterling.

Terborgh, J. (1999) Requiem for nature. 234 pp, Island Press, Washington. D.C.

Terborgh, J. and Peres, C. A. (2002) The problem of people in Parks. In Making parks work: strategies for preserving tropical nature. Terborgh, J., van Schaik, C., Davenport, L., and Rao, M. (eds.), Island Press, Washington, D.C., 307-319.

Terborgh, J. and Schaik, C.V. (2002) Why the world needs parks. In Making parks work: strategies for preserving tropical nature. Terborgh, J., van Schaik, C., Davenport, L., and Rao, M. (eds.), Island Press, Washington, D.C., 3-14.
Tisdell, C.A. (1995) Issues in biodiversity conservation including the role of local communities. Environ. Conserv. $22: 216-222$.

鳥越皓之（1989）経験と生活環境主義．（環境問題の社会理論一生活 環境主義の立場から.鳥越堌之編, $216 \mathrm{pp}$, 御茶の水書房, 東 京). 14-53

鳥越堌之（1997）環境社会学の理論と実践：生活環境主義の立場か 5. $280 \mathrm{pp}$, 有斐閣, 東京.

土屋俊幸・藤原千尋・山本信次（2003）国立公園の管理政策と地域社 会一ベトナム・タムダオ国立公園。(アジアにおける森林の消失 と保全. $324 \mathrm{pp}$, 井上 真編, 中央法規, 東京). 237-25.

Wells, M., Guggenheim, S., Khan, A., Wardojo, W., and Jepson, P. (1999) Investing in biodiversity: a review of Indonesia's integrated conservation and development projects. $119 \mathrm{pp}$, The World Bank, Washington, D.C.

横田康裕（2003）地域住民からみた「森林破壊」一インドネシアの産 業造林事業. (差別と環境問題の社会学. $220 \mathrm{pp}$, 桜井 厚・好井 裕明編，新曜社，東京）。163-183.

\section{注記}

（注 1）IUCN (1994: 7) は，保護地域を「生物多様性，自然やそれに 関わる文化的資源の保護や管理に特化し，合法的または他の効果的な 方法によって管理された土地や海の領域」と定義している。保護地域 の数および面積の推移, 保護地域の価值などについての詳細な情報 は，原田（2003a, b, c) を参照のこと。

（注 2）尾関（1995）は，共生という概念は，現代生物学の進化論に おいて指摘されてきた概念であるとした上で,ダーウィンの進化論に おける, 同種の他の個体とのあいだの生存競争や環境との生存競争と は異なる, 異種どうしの相互作用を強調するものであると指摘してい る。しかし，ここでいう自然と人間の共生とは，秋道(1999) が指摘す るように, 生態学的な意味での共生とは異なり, 人間と動植物が一元 的な関係によって結ばれるのではなく,様々な関係性をもつという共 存の思想と同義である。

（注 3）鬼頭（1996: 120-122）は，近代の自然と人間の対立図式を脱 却し，自然や人間を独立して存在する実体としてではなく，両者の間 の「かかわり」という関係性を全体的に捉えるあり方，「かかわりの 全体性」が新たな見方となってくると指摘している。この理念は「新 エコロジカル・パラダイム」にも通じるものである。

（注 4）鬼頭（2002）は, 人間と自然の関係を, 環境持続性, 社会的公 正，存在の豊かさという三つの要素によって類型化した。この類型で は, 生命中心主義や生態系中心主義は環境持続性として, 動物の解放 やディープ・エコロジーは存在の豊かさとして分類されている。しか し, 本論文では生命中心主義は自然と人間の関係を統括的にとらえる 枠組みを構成する要素としてとらえることとした。

（注 5）例えば，「オリエンタリズム，パターナリズム，コミューナリ ズム」や「ディープ・エコロジー, シャロー・エコロジー」など, 対 になる思想が既存の一つの軸の上で議論できるわけではないこと, 前 節であげた思想の中には, グローバルな共生にあてはまる思想がない ことなどが明らかになった。

（注 6）熱帯の国々においては, ICDP は, (1)保護地域の生物多様性の 急激な減少を緩和する可能性を秘めている, (2)平等主義に基づいて地 域住民に利益を提供することができる，(3)生物多様性に利用できる大 部分の国際的な資金を引きつけることができる，という理由で重要で あるとされている (Wells et al., 1999: 11)。

（注 7）エコ・ツーリズムは, 保護地域のみで行われているものではな いが, 特に, 世界中の国立公園などの保護地域において, エコ・ツー リズムが盛んに行われており，多くの国の国家戦略の一つとなってい る。

（注 8）Nash (1989）によれば，エコ・ツーリズムの潮流は，新しい 西洋の帝国主義の波であり，ツーリズムやエコ・ツーリズムは，植民 地主義を誘発している。

(注 9) Elmandjra (1996 (2002 訳)：128）は, 西洋的価値観の推進者 たちは，自らの価值，民主主義，人権，正義，公平，合理性，科学的 方法, テクノロジー, 美学などについてのあらゆる考え方を「普遍性」 の名の下にとらえてしまうという大きな過ちを犯しており，このよう な態度は文化的傲慢以外の何ものでもなく, 文化的植民地主義である と指摘している。 
（注 10）佐藤（2004）によれば, 住民組織化には,「効率のための組織 化」「公正のための組織化」，「エンパワーメントのための組織化」の 三つがある。「効率のための組織化」とは，多くの人が集まることに よって, 生産活動や資源調達が効率的に行われ, 生産の向上につなげ るための組織化である。「公正のための組織化」とは，発言機会が与え られなかったり, 経済的資源へのアクセスが与えられなかったりする 「社会的弱者」あるいは「経済的弱者」が団結し, 発言機会を確保する ための組織化である。「エンパワーメントのための組織化」とは, 通常
は発言機会が得られない個々人が, 組織化の過程でエンパワーメント を達成するための組織化である。ここでいう組織化とは「公正のため の組織化」である。

（注 11）住民組織化にあたっては，村落内にある，森林管理組織，農 業組織，青年組織といった既存の組織を利用する場合と，まったく新 たに組織を結成する場合とが考えられる。いずれの場合も，今までの 社会的文化的な慣習を保ちつつも，保護地域の目的に沿った交渉およ び，管理の実施を担うことができる住民組織である必要がある。 